1997

\title{
Democratic Excess in the Use of Zoning Referenda
}

Karin M. Mika

Cleveland State University, k.mika@csuohio.edu

Aaron J. Reber

)

Follow this and additional works at: https://engagedscholarship.csuohio.edu/fac_articles

Part of the Urban Studies and Planning Commons

How does access to this work benefit you? Let us know!

Original Citation

Karin Mika, Democratic Excess in the Use of Zoning Referenda, 29 Urban Lawyer 277 (1997)

This Article is brought to you for free and open access by the Faculty Scholarship at EngagedScholarship@CSU. It has been accepted for inclusion in Law Faculty Articles and Essays by an authorized administrator of EngagedScholarship@CSU. For more information, please contact research.services@law.csuohio.edu. 


\section{HEINONLINE}

Citation: 29 Urb. Law. 2771997

Content downloaded/printed from

HeinOnline (http://heinonline.org)

Fri May 18 09:37:48 2012

-- Your use of this HeinOnline PDF indicates your acceptance of HeinOnline's Terms and Conditions of the license agreement available at http://heinonline.org/HOL/License

-- The search text of this PDF is generated from uncorrected OCR text.

-- To obtain permission to use this article beyond the scope of your HeinOnline license, please use:

https://www.copyright.com/ccc/basicSearch.do?

\&operation $=$ go\&search Type $=0$

\&lastSearch $=$ simple\&all $=$ on\&titleOrStdNo $=0042-0905$ 


\title{
Democratic Excess in the Use of Zoning Referenda
}

\author{
Aaron J. Reber \\ Associate, Chattman, Gaines \& Stern, L.P.A., \\ Cleveland, Ohio; \\ J.D., Cleveland-Marshall College of Law; \\ B.A., Valparaiso University.
}

\section{Karin Mika}

Assistant Director, Legal Writing, Research \& Advocacy, J.D., Cleveland-Marshall College of Law;

B.A., Baldwin-Wallace College.

A SHORT NEWS ANNOUNCEMENT READS, "Residents are being asked for the second time to change zoning laws to allow for a new zone for two-family dwellings. Officials said they believe the issue was defeated in November because the language on the ballot was confusing."' This short newspaper announcement exemplifies the problems for voters of confusing ballot language-a problem that has plagued elections in recent years. While the general theory might be that politicians or special interest groups purposely confuse the issues so that their side is unwittingly approved by the general public, the truth is that confusing ballot language has as much chance to thwart decent legislation as it does to surreptitiously cause an undesirable law to be enacted. ${ }^{2}$

To that end, there is a problem when a mandatory public referendum is required to approve what a planning committee, elected by the general public, has already approved. Although the purpose of mandatory referenda has been to provide a "check" on the powers of such a governmental entity, this check loses its efficacy when either poor voter turnout or confusing ballot language thwart what might very well be the desire of the electorate at large. When that happens, the mandatory referendum is an unnecessary, costly, and even delaying process.

The concept of the mandatory referendum is often associated with approving or disapproving a zoning enactment of a particular municipal-

1. Important Issues Face Voters; More than 60 in the Area to be Settled on Tuesday; One-Third are Nonschool, AKRon BEaCON J., May 28, 1992, at B3.

2. See, e.g., Jim East, Sentiments Same for Stadium Vote, The Tennesseean, May 6, 1996, at 1A; Hollace Silbiger, Avon Faces Big Bills from Fees in 3 Lawsuits, Cleveland Plain Dealer, Dec. 19, 1994, at 1B; Sue Kiesewetter, Levy Supporters to Knock on Doors in Mt. Healthy, Cincinnati Enquirer, May 22, 1994. 
ity. The power of zoning has traditionally been a power of local selfgovernment. ${ }^{3}$ In order to comport with due process principles, legislative enactments that allow for zoning generally include provisions that such legislation be adopted when two conditions have been met: First, when a detailed study of the regulation and development plans has been made; and second, when it is apparent any measures so adopted would coincide with and be conformable to an overall and comprehensive plan for the municipality. ${ }^{4}$ These requirements have been enough to satisfy the criteria necessary to show a zoning ordinance is neither arbitrary or unreasonable, nor amounts to an unconstitutional taking of property. ${ }^{5}$

Within their city charters, municipalities often have referendum provisions. These require the electorate to decide the final fate of a proposed zoning enactment. ${ }^{6}$ While referendum power is reserved or granted to the people of a municipality, courts have been required to decide whether referendum power has been constitutionally exercised, and whether such power has been lawfully delegated.

Associated with the power of referendum are competing social and civic policies. On one hand, it may be in the best interests of the municipality to allow comprehensive zoning proposals planned by experts and adopted by elected officials. On the other hand, legislative action by a select few is against a philosophy of wider public participation and choice in municipal affairs to be accomplished through a broad and liberal extension of the referendum power. ${ }^{7}$

The ultimate question is what is in the best interests of the people. The Constitution requires any taking of land to comport with principles of due process. ${ }^{8}$ If the Supreme Court has determined due process is

3. See generally Eubank v. City of Richmond, 226 U.S. 137 (1912).

4. See, e.g., Ala. CODE $\$ 11-52-9$ (1975); Alaska STat. \$ 11-806 (Michie 1939); Ark. Code AnN. $\S 14-56-414,14-56-505$ (Michie 1955); Cal. Gov. Code $\S 65850$ et seq. (West 1975); Colo. Rev. Stat. § 30-28-131 \& \& 31-23-207 (1975); ConN. Gen. Stat. \& 8-36 (1995); Del. Code ANN. tit. 9 \& 2656, \& 4956 \& \& 6956 (1975); IND. CODE $\S 36-7-4-504$ (1996); Mich. STAT. ANN. $\$ 125.19 \& \& 125.37$ (Law Co-op. 1996); MinN. STat. $\$ \S 462.356,462.357$ (1996); Mo. Rev. Stat. $\$ 89.350$ (1996); OkLa. Stat. $\S 47-107$ (1996); 16 Pa. Cons. Stat. \& 5210 \& 53 Pa. Cons. STat. § 10607 (1997); S.C. Code AnN. § 5-23-500 (1995); S.D. Codified Laws § 11-6-15 (Michie 1996); Tex. Local Gov't Code ANN. § 231.079 (West 1995); VA. Code AnN. § 15.1-447 (Michie 1996); W. VA. CODE $\$ 8-24-17$ (1996).

5. See generally Euclid v. Ambler Realty Co., 272 U.S. 365 (1926).

6. See generally Ronald H. Rosenberg, Referendum Zoning: Legal Doctrine and Practice, 53 U. Cin. L. Rev. 381 (1984).

7. See generally Nicolas M. Kublicki, Land Use by, for, and of the People: Problems with the Application of Initiatives and Referenda to the Zoning Process, 19 PEPP. L. REV. 99, 99 (1991).

8. U.S. Const. Amend V. 
satisfied when a restriction on property bears some "rational relation to the public health, safety, morals, or general welfare," a potential conflict when a referendum conceivably gives voters the power to arbitrarily prevent their neighbors' chosen use of land after a planning committee has already decided particular zoning is related to health, safety, morals, or general welfare. ${ }^{10}$ Moreover, given the nature of how zoning issues are presented to the general public, it is questionable whether mandatory referendum accomplishes anything at all, except as another layer of bureaucracy.

This article will argue that while mandatory referendum might not be an unlawful delegation of legislative powers, it might be an unnecessary step that actually thwarts zoning legislation. With limited voter turnouts and the complexity of ballot language on zoning issues, voters may knowingly or unknowingly regulate a neighbor's property use, and additionally may knowingly or unknowingly hinder the efforts of city planners who have painstakingly attempted to regulate land use in compliance with what would otherwise be regarded as constitutionally acceptable guidelines. The article argues that the Supreme Court's conclusion in Eastlake v. Forest City Enterprises, Inc. " that referenda are constitutional because their results may be challenged, is not a realistic vision of the zoning process as it now exists. Rather the Supreme Court's previous standards articulated in Euclid v. Ambler Realty $\mathrm{Co}^{12}$ and Moore v. East Cleveland ${ }^{13}$ should be sufficient to ensure an efficient process of municipal management without the necessity of challenging the results of a public referendum.

\section{History of Zoning Regulation}

Many states have adopted state constitutional provisions that grant municipalities the authority to exercise powers of local self-government and to adopt and enforce regulations that are related to the health and safety of the municipality. These provisions are often referred to as "Home Rule" Amendments. ${ }^{14}$ There have been many areas in which

9. Euclid, 272 U.S. at 392.

10. State of Washington v. Roberge, 278 U.S. 116 (1928).

11. 426 U.S. 668 (1976).

12. 272 U.S. 365 (1926).

13. 431 U.S. 494 (1977).

14. See, e.g., Art. XVIII, $\S 3$, of the Ohio Constitution which states, "Municipalities shall have authority to exercise all powers of local self-government and to adopt and enforce within their limits such local police, sanitary, and other similar regulations, as are not in conflict with general laws." 
citizens have tested the extent of the "Home Rule" power. ${ }^{15}$ One of these areas is municipal zoning, and in particular, residential zoning. Although residential zoning cases have seldom come before the Supreme Court of the United States, there have been various landmark cases addressing the issue and its offshoots. In 1926, comprehensive zoning received near blanket approval in the case of Euclid v. Ambler Realty Company. ${ }^{16}$

In Euclid, the U.S. Supreme Court upheld the constitutionality of a village's comprehensive zoning plan for regulating and restricting such things as location of trades, industries, apartment houses, family homes, lot sizes, and the height of village buildings. ${ }^{17}$ The plaintiff, who owned a tract of land which he intended to sell and develop for industrial use, sought to enjoin the enforcement of the zoning ordinance which prohibited an industrial use of his land. The ordinance was attacked on the ground that it was a violation of the Due Process Clause. The Court, however, found justification for the village's zoning regulations rooted in the police powers of a municipality. ${ }^{18}$ While noting that the line that separates the legitimate from the illegitimate assumption of powers was not capable of precise delineation, the Court found that if the validity of a legislative classification for zoning purposes be fairly debatable, the legislative judgment must be allowed to control. ${ }^{19}$

The Court then confronted an issue that it had not addressed beforethe validity of an ordinance that created residential districts from which businesses and trades of every sort were excluded. The Court commented that the matter of zoning had received much attention at the hands of commissions and experts who concurred that the segregation of residential, business, and industrial buildings would make it easier to provide fire apparatus suitable for the character and intensity of the

15. See, e.g., City and County of Denver v. Colorado, 788 P.2d 764 (Colo. 1990) (challenging residency requirements as unconstitutional); Illinois Gasoline Dealers Ass'n v. City of Chicago, 491 N.E.2d 112 (IIl. App. Ct. 1986) (challenging constitutionality of gasoline tax); Sioux City Police Officers' Asso'n v. Sioux City, 495 N.W.2d 687 (Iowa 1993) (challenging antinepotism policy as unconstitutional); Koricili v. DeKalb County, 324 S.E.2d 450 (Ga. 1985) (challenging constitutionality of liquor licensing); Tops Markets, Inc. v. Erie, 591 N.Y.S.2d 694 (N.Y. 1992) (challenging item pricing law as unconstitutional); City of Rocky River v. State Empl. Rel. Bd., 530 N.E.2d 1 (Ohio 1988) (challenging constitutionality of binding arbitration clause).

16. 272 U.S. 365 (1926). For a discussion of the constitutional status of state zoning regulations prior to Euclid, see Robert F. Benintendi, The Role of the Comprehensive Plan in Ohio: Moving Away from the Traditional View, 17 U. DAYTON L. REV. 207 (1991).

17. 272 U.S. at $379-80$.

18. Id. at 387 .

19. Id. at 388 . 
development in each section..$^{20}$ Furthermore, the segregation would increase the safety and security of home life, greatly tending to prevent street accidents by reducing traffic and resulting confusion in residential areas. ${ }^{21}$ Summarizing, the Court stated that the policy reasons given for having segregated residential districts were sufficiently cogent to prevent the Court from concluding that such provisions were clearly arbitrary and unreasonable, having no substantial relation to the public health, safety, morals, or general welfare. Therefore, the ordinance could not be ruled to be unconstitutional. ${ }^{22}$

The Supreme Court confirmed its stand on the issue of the constitutionality of zoning regulations in a few decisions following Euclid in the $1920 \mathrm{~s} .{ }^{23}$ Nevertheless, since Euclid was decided, the Court essentially divorced itself from zoning cases for nearly half a century and did not begin to participate in the growing body of zoning law again until 1970 s. ${ }^{24}$ Upon re-entering the field, it was clear that the Court was reluctant to alter the established standard. The Court's general rule that a zoning regulation would be upheld as constitutional unless it had no substantial relationship to the public health, safety, morals, or general welfare reflected its reluctance to enter the zoning area by deferring to the legislative body. Moreover, in Warth v. Seldin, ${ }^{25}$ the Court commented that zoning laws and their provisions were peculiarly within the province of local and state legislative authority and were essential to effective urban planning. The Court stated that zoning laws were subject to judicial review in a proper case, but that citizens dissatisfied with provisions of such laws need not overlook the availability of the normal democratic process. ${ }^{26}$

Under that line of reasoning, the Court limited its review of zoning cases to matters provoking special review. In an era of racial discrimination, the Court was more concerned with the use of zoning and land

20. Id. at 393.

21. Id. at 394.

22. 272 U.S. at 395.

23. See Goreb v. Fox, 274 U.S. 603 (1927) (upholding a zoning regulation because the regulation was clearly arbitrary and unreasonable, having substantial relation to the health, safety, morals, or general welfare of the municipality).

24. For a comprehensive discussion of the history of zoning cases, see Quintin Johnstone, Government Control of Urban Land Use: A Comparative Major Program Analysis, 39 N.Y. L. SCH. L. Rev. 373 (1994).

25. 422 U.S. 490 (1975).

26. Ironically, in Warth, the Court held that none of the plaintiffs in the case had standing to sue because they failed to establish an actionable causal relationship between the zoning restrictions and the asserted injury. The Court stated that a plaintiff who sought to challenge exclusionary zoning practice was required to allege concrete facts demonstrating that the challenged practice harmed him, and that he personally would benefit from the court's intervention. Id. at 508 . 
control as a way to discriminate against minorities. ${ }^{27}$ Rather than analyzing cases under the standard enunciated in Euclid, the Court found ways to strictly scrutinize ordinances that may have been enacted merely to discriminate. For instance, in Moore v. East Cleveland ${ }^{8}$ five members of the Court agreed that the Due Process Clause of the Fourteenth Amendment was violated by a housing ordinance that limited occupancy of a dwelling unit to members of a single family. The ordinance defined family as only a few categories of related individuals, essentially parents and their children. Rather than apply the constitutional standard enunciated in Euclid, which would have only required a rational basis for the ordinance, the Court held that Euclid did not apply because the ordinance was aimed at regulating the family. Instead, the Court commented that it must apply a stricter standard of review to guarantee that the State is not intruding on the "private realm of family life which the state cannot enter." 29

The general rule with respect to most zoning regulations is that a zoning regulation will be upheld as constitutional unless it has no rational relationship to the public health, safety, morals, or general welfare. Due to the local nature of land planning and development, this low standard of review is easily met by a municipality that passes an ordinance pursuant to a commission's recommendations or a planning initiative. ${ }^{30}$ Ordinances adopted in an effort to stem the flow of traffic into a municipality have been recognized as substantially related to the health and safety of citizens. ${ }^{31}$ General environmental concerns, such as pollution, as well as enhancing quality of life by reducing noise, traffic hazards, and litter are sufficient to meet the low constitutionality standard..$^{32}$ Thus, a municipality's making a plan based simply on welfare concerns has a good chance of remaining in effect. ${ }^{33}$ Nevertheless, state and local legislators have reserved and exercised their right to

27. See, e.g., Village of Arlington Hts. v. Metro. Housing Dev. Corp., 429 U.S. 252 (1977).

28. 431 U.S. 494 (1977).

29. Id. Justices Powell, Brennan, Marshall, and Blackmun all expressed the views of the opinion which announced the decision of the Court. Justice Stevens concurred, stating that while the Euclid decision vastly diminished the rights of individual property owners, it did not totally extinguish those rights. Moreover, broad zoning powers must be exercised within constitutional limits.

30. But see City of Cleburne, Tex. v. Cleburne Living Ctr. Inc., 473 U.S. 432 (1985) (mental retardation not a suspect class, but no rational basis to suppose group home would pose a threat).

31. See County Bd. of Arlington County v. Richards, 434 U.S. 5 (1977).

32. Id.

33. See Jerold S. Kayden, Land-Use Regulations, Rationality, and Judicial Review-The RSVP in the Nollan Invitation, 23 URB. LAw. 301 (1991). 
referendum, and have essentially added another, perhaps unnecessary, step to the zoning enactment process.

\section{Mandatory Referendum}

The term "referendum" is defined as the power reserved to the people, in some jurisdictions, to approve or reject at the polls an enactment of a legislative body. ${ }^{34}$ The right of the electors of a municipality to exercise this power exists by virtue of express provisions of the state constitution..$^{35}$ The power of referendum may also be established by a charter provision adopted by a municipality and approved by the legislature, or by municipal enactment. ${ }^{36}$

The constitutionality of referendum power was first challenged before the U.S. Supreme Court in the case of Eubank $v$. City of Richmond ${ }^{37}$ In Eubank, the city council of Richmond passed an ordinance that required the "Committee on Streets" to establish a "building line",38 for a piece of property at the request of two-thirds of the abutting property owners. The ordinance left no discretion to the "Committee on Streets" as to whether the building line should be established at all. Instead, their actions were dictated by two-thirds of the abutting owners. ${ }^{39}$

The Court held that the control of the use of the owner's property by that owner's neighbors was a violation of the Due Process Clause because it constituted an unreasonable exercise of police powers. ${ }^{40}$ The court stated,

It leaves no discretion in the committee on streets as to whether the street line shall or shall not be established in a given case. The action of the committee is determined by two-thirds of the property owners. In other words, part of the property owners fronting on the block determine the extent of use that the owners shall make of their lots, and against the restriction they are impotent. This we emphasize. One set of owners determines not only the extent of use, but kind of use which another set of owners may make of their property. In what way is the public safety, convenience, or welfare served by conferring such power? The statute and ordinance, while conferring the power on some property holders to virtually control and dispose

34. 42 AM. JUR. 2d, Initiative and Referendum $\$ 1$ (1969).

35. See David L. Callies, Nancy C. Neuffer \& Carlito P. Caliboso, Ballet Box Zoning: Initiative, Referendum and the Law, 39 WASH. U.J. URB. \& CONTEMP. L. 53 (1991).

36. See Id.

37. 226 U.S. 137 (1912).

38. A line past which no buildings could be erected.

39. Id. at 143 .

40. Id. at 144 . 
of the property rights of others, creates no standard by which the power thus given is to be exercised. ${ }^{41}$

The next case dealing with the constitutionality of mandatory referendum was decided soon after the Supreme Court promulgated the general constitutionality of zoning enactments in Euclid. The case of Washington v. Roberge $e^{42}$ reiterated a zoning ordinance's general presumption of constitutionality, however, it also addressed a referendum issue similar to Eubank. In Roberge, an owner of property wanted to construct a home for the aged; however, there was an ordinance which permitted the establishment of such a home only upon the consent of two-thirds of the property owners within a certain distance of the proposed building. ${ }^{43}$

In deciding the case, the Court emphasized that zoning measures must find their justification in the police power exerted in the interest of the public and that legislatures must not, under the guise of the police power, impose restrictions that are unnecessary and unreasonable upon the private property or the pursuit of useful activities. ${ }^{44}$ The Court was particularly interested in the procedure that was in place when deciding zoning measures and who had the authority to make a decision that affected a property owner's rights. The Court found that the purpose of the proposed building was in line with the plans of the zoning regulation's plans, ${ }^{45}$ but questioned the city ordinance on the books which required the surrounding landowner's consent. That delegation of power, the Court ruled, was repugnant to the Due Process Clause of the Fourteenth Amendment. To that end, the attempted delegation of power to the surrounding neighbors, through mandatory referendum, was invalid and the permit to build the home was granted. ${ }^{46}$

After initially striking down the constitutionality of mandatory referendum as applied to a zoning ordinance, the Court revisited this aspect of zoning regulation in the case of Eastlake v. Forest City Enterprises, Inc. ${ }^{47}$ In Eastlake, a city charter provision required that proposed land use be ratified by 55 percent of the votes cast. ${ }^{48}$ The plaintiff, a real estate developer, acquired a parcel of land that was zoned "light industrial." He applied to the city for a zoning change to permit construction of a multi-family, high-rise apartment building and then attempted to

41. Id. at 143 .

42. 278 U.S. 116 (1928).

43. $I d$. at 118 .

44. Id. at 120-121.

45. Id.

46. Id. at 122-23.

47. 426 U.S. 668 (1976).

48. Id. 
invalidate the referendum provision as an unconstitutional delegation of legislative powers. While the case was pending, the action was submitted to referendum but was not approved. ${ }^{49}$ The Court of Common Pleas and the court of appeals ultimately upheld the referendum provision; however, on appeal, the Ohio Supreme Court reversed. ${ }^{50}$ The Ohio Supreme Court concluded that "a popular referendum requirement, lacking standards to guide the decision of the voters, permitted the police power to be exercised in a standardless, hence arbitrary and capricious manner." 51 After granting certiorari, the U.S. Supreme Court reversed, upholding the referendum requirement. ${ }^{52}$

In a different line of reasoning from Eubank and Roberge, the Court held that a referendum, which it defined as direct political participation by the people allowing for what amounts to a veto power over legislative enactments, could not be characterized as a delegation of power. ${ }^{53}$ Because the power of referendum was specifically reserved to the people under the Ohio Constitution, the people could directly deal with matters that might otherwise be assigned to the legislature. ${ }^{54}$ The Court distinguished cases in which the legislature delegated "approval" power to regulatory agencies which were not "directly responsible to the people." 55 The Court further stated that the referendum result could itself be challenged as arbitrary and capricious, and consequently, the mandate of a public referendum to approve a zoning ordinance was deemed a constitutional exercise of power. ${ }^{56}$

In his dissent, Justice Stevens changed the focus of the analysis and expressed concern for the property rights of an individual and whether the mandatory referendum requirement was fundamentally fair. ${ }^{57}$ Because no challenge was made by either party that the individual property owner's intended use ran afoul of the municipality's zoning plan or was in contravention of the health and welfare of the general public, the dissent focused on the procedures involved. Justice Powell gave deference to the conclusion of the Ohio Supreme Court's decision that the procedure represented an arbitrary and unreasonable way of

49. Id.

50. 324 N.E.2d 740 (Ohio 1975).

51. 426 U.S. at 671.

52. Id. at 672 .

53. Id.

54. See also Rispo Invest. Co. v. City of Seven Hills, 629 N.E.2d 3 (Ohio Ct. App. 1993).

55. Id. at 675 .

56. Id. at 676 .

57. Eastlake, 426 U.S. at 680. 
handling a local problem..$^{58} \mathrm{He}$ agreed with the logic of the Ohio Court that a mandatory citywide referendum which applied to any zoning change would, of necessity, submit a decision affecting one person's use of his property to thousands of voters with no interest in the property whatsoever. In the lower court's opinion, Ohio Supreme Court Justice Stern had given the example that by such a provision, rezoning a corner gasoline station on one end of town would require the approval of thousands of voters, most of them living miles away, and few of them with the slightest interest in the matter. ${ }^{59}$ Justice Stevens stated that although conceivably a small parcel, such as an eight acre development, could be sufficient to arouse the legitimate interest of the entire community, it was equally conceivable that most of the voters would be uneducated and uninformed about a proposed zoning ordinance, thus leading to a fundamentally unfair procedure that was arbitrary in nature. ${ }^{60}$

Both the Court in Roberge and the dissent in Eastlake echo a similar rationale for holding that mandatory referendum procedures regarding zoning ordinances should be unconstitutional. In both cases, the Supreme Court was concerned with the arbitrary nature of the general electorate vote as being a necessary part of a zoning ordinance's fate. Requiring such a step brings about two general concerns. First, as Roberge discussed, is the individual property owner's right to use his property for whatever purpose he desires and other property owners' inability to arbitrarily prevent that use of land. Second, is the arbitrary nature of the voting process and the effect that the general electorate's inability to understand a zoning ordinance as requiring an arbitrary determination of the validity of such ordinance.

Subsequent to Eastlake, state courts have addressed the constitutionality of mandatory referenda in various situations, with one of the focal points being on whether the land use decision can be classified as a "legislative" decision, as opposed to an "administrative" one. Since only those classified as legislative decisions may be exposed to the general electorate, a referendum may follow on a zoning decision only if the decision is characterized as legislative, but not if characterized as an administrative action. This is exemplified by Leonard $v$. City of Bothell $^{61}$ in which the Washington Supreme Court held that while the enactment of a zoning ordinance was legislative (subject to referendum),

58. Id. at 686 .

59. Id. at 690 .

60. Id. at 694 .

61. 557 P.2d 1306 (Wash. 1976). 
an amendment to a zoning ordinance was administrative (not subject to voter approval). Another avenue for avoiding an obligatory public referendum is declaring that a "rezoning"' is an adjudicative function that gives with it guarantees of due process that will not be subject to the general electorate. ${ }^{62}$ While various states agree with the assessment of rezoning being a nonlegislative act, most state courts have determined that both zoning and rezoning are legislative acts subject to voter approval. ${ }^{63}$ In rationalizing this view, Justice Tobriner, writing for the California Supreme Court in Arnel Development Co. v. City of Costa Mesa ${ }^{64}$ stated that to make such a distinction between legislative act and nonlegislative act would predicate determining a legislative action on the basis of the size of property effected ${ }^{65}$ Tobriner concluded that such a distinction would result in uncertain application of policy because what was a small parcel in one municipality might be a large parcel in another municipality.

These cases illustrate the difficulties of the referendum process, especially with respect to zoning. Justice Tobriner is correct in positing that differentiating between administrative actions, legislative actions, and judicial actions causes its own bureaucratic problems; however, declaring a zoning or rezoning action legislative so that a mandatory referendum is warranted does not solve any of the bureaucratic problems the referendum itself causes. State zoning acts already include within them an adherence to constitutionality and mandate that an ordinance be passed "in accordance with a comprehensive plan." 66 Adding the additional tier of mandatory referendum is, at times, a superfluous and self-defeating gesture as the general electorate tends not to have any comprehensive plan in mind when voting on a particular issue. ${ }^{67}$

Several scholarly treatises have commented on the inefficiency of direct electorate decision making in other areas of the law in both the realm of initiative and of referendum. ${ }^{68}$ In the 1994 comment, Interpretation of Initiatives by Reference to Similar Statutes: Canons of Construction Do Not Adequately Measure Voter Intent, ${ }^{69}$ Stephen

62. See Mark W. Cordes, Policing Bias and Conflicts of Interest in Zoning Decisionmaking, 65 N.D. L. REv. 161, 188-91 (1989).

63. For a comprehensive list of these cases, see Kublicki, supra note 9, at notes $194-95$.

64. 620 P.2d 565 (Cal. 1980).

65. Id. at 523.

66. Kublicki, supra note 9 at 101.

67. Id.

68. An initiative is a petition begun by the electorate. A referendum follows an ordinance already enacted.

69. 34 Santa Clara L. Rev. 945 (1994). 
H. Sutro critiques California's initiative process. Sutro states that although the initiative process "sought to further public discussion of important issues ... it is unclear to what extent the initiative process has succeeded in achieving these noble goals. "70 In reaching his assessment, Sutro points to the overburdening of courts with "tremendous amounts of litigation due to ambiguity in initiative language," and further overburdening due to constitutional challenges. ${ }^{71}$

Thomas Gais and Gerald Benjamin reach a similar conclusion regarding the initiative process in potential constitutional reform. In Public Discontent and the Decline of Deliberation: A Dilemma in State Constitutional Reform, ${ }^{72}$ the authors conclude,

Voters' choices are sometimes affected by highly emotional, symbolic appeals triggering general hostility toward bureaucrats and politicians. Moreover, voters are frequently confused by the technical language of ballot propositions. Many voters learn about initiatives only days before elections, often rely on just one source of information, and rarely discuss the issues with other citizens. The fate of initiatives also seem to be largely influenced by how much money is spent on the proposals, particularly by their opponents. ${ }^{73}$

The authors further comment that "initiatives are not very representative," because the elections suffer from low turnout and that the issues "are often decided by a minority of voters whose preferences frequently differ from state citizens as a whole." 74

In Direct Democracy: The Right of the People to Make Fools of Themselves; The Use and Abuse of Initiative and Referendum, a Local Government Perspective, ${ }^{75}$ Daniel M. Warner chronicled the trials and tribulations of the initiative and referendum process in Whatcom County, Washington, from 1983 through 1991. Warner's observation was that the initiative (or referendum) process accomplished little more than disrupting legitimate governmental plans, enacting unconstitutional ordinances, delaying solutions that might have been implemented earlier in time, and costing the taxpayers expense because of government work-hours dedicated to the complications associated with the process (such as litigation). ${ }^{76}$

With respect to zoning specifically, Warner detailed the referendum challenge of Whatcom County directed at Washington State's "Growth

70. Id. at 945 .

71. Id. at 947 .

72. 68 TEMP. L. REV. 1291 (1995).

73. Id. at 1301-02.

74. Id. at 1302.

75. 19 Seattle U. L. Rev. 47 (1995).

76. Id. at 75. 
Management Act" - an Act passed to "encourage orderly growth and development in certain counties in the state." In accordance with the Act, Whatcom County, through a technical advisory committee and a citizens' advisory group, began "the process of defining and, by ordinance, limiting the use of, intrusion into, and exploitation of wetlands, steep slopes, alluvial plains, and other critical areas within the County." "77

In response to what had become what was known as the "Critical Areas Ordinance," a rather radical coalition emerged with the intent to derail any ordinance by causing disruptions of city council meetings and emphasizing publicly that environmental regulations were actually a denigration of individual land rights. ${ }^{78}$ After the Council adopted a "Critical Areas Ordinance,"' it was submitted to referendum. ${ }^{79}$ After a campaign that essentially misconstrued what the ordinance intended to do, the referendum derailed attempts to protect areas in the county. ${ }^{80}$

After the referendum vote had thwarted what had originally been an Act by the State of Washington, the county challenged the referendum process. First, the Western Washington Growth Management Hearings Board declared the referendum illegal, and then the Washington Supreme Court concurred. ${ }^{81}$ Warner points to the following rationale for the court's decision:

First, the court found the "power to act under the [state] Growth Management Act was delegated to the "county legislative body,' " and is not, therefore, subject to referendum. Second, the court found that the entire purpose of state-wide planning would be jeopardized by allowing counties to effectively repeal state law through referenda. Third, the court held that the ordinance was adopted to promote "public health [and] safety," and such ordinances cannot, under the county charter, be amended by referenda. Fourth, the court held that the process of adopting the amended ordinance did not comport with state law under the Planning Enabling Act, which requires a whole process of "commissions and planning agencies, and further describes the procedural functions of each" before adoption of any landuse planning law under the Act. ${ }^{82}$

What the Washington Supreme Court points to is that the process appeared to be constitutional as it was without the referendum, and that the use of the referendum did little more than thwart what had been appropriate legislation enacted via appropriate channels.

77. Id. at 70 .

78. Id. at 70-73.

79. Id. at 73 .

80. Id.

81. Whatcom County v. Brisbane, 884 P.2d 1326 (1994). bane).

82. Warner, supra note 77 , at 75-76 (quoting, in part, Whatcom County v. Bris- 
Finally, in a research project conducted in Ohio that examined the Cuyahoga County election records from 1962 to 1982, Ronald H. Rosenberg came to the conclusion that subjecting zoning changes to mandatory referendum did not accomplish the goal of advancing comprehensive plans for a community as the passage or lack of passage seemed based on arbitrariness. ${ }^{83}$ The study found that over the study period, land-use referenda were successful 61 percent of the time, with only 48 percent being passed that concerned single parcel rezoning. ${ }^{84}$ Although the results did not reflect a picture of complete hostility to all zoning changes, the author noted that most of the unsuccessful referendum proposals would have been enacted into local law absent the plebiscite requirement. ${ }^{85}$ The study indicated a high success rate for zoning referendum following the Eastlake decision that could be attributed either to a greater number of zoning referenda proposed to the general electorate or a blind confirmation of decisions previously made by city councils on matters of land-use policy. ${ }^{86}$ Analyzing all of the data compiled, the author concluded that there was no clear pattern regarding the success or the failure of the zoning ordinances. Not surprisingly, one of the findings in his research was that the ballot language employed for land-use referenda within the study area was confusing and occasionally incomprehensible. ${ }^{87}$

Although a mandatory zoning referendum might be for the purpose of encouraging an enlightened form of participatory democracy, an interested voter's effectiveness is limited to the language on the ballot. The result might very well be an arbitrary determination of whatever issue is presented to the voter. Moreover, Rosenberg's study indicated that voter turnout as a whole had been very low, leaving the fate of the zoning ordinance up to a small percentage of eligible voters within the jurisdiction. ${ }^{88}$ As the author of the survey concluded, the zoning mechanism used by a variety of municipalities in Cuyahoga County was conspicuously undemocratic. By requiring referendum, the ability to establish community goals and to implement them through legislative action is withdrawn from the popularly elected representatives. More

83. See supra note 8.

84. Id. at 428 . Single parcel rezoning often deals with a variance that a business might ask for.

85. Id. at $429-30$.

86. Id. Due to the blind affirmation of proposed ordinances, the author of this study questioned the effectiveness of mandatory referendum and the costs that such a system placed on municipalities, due to the unnecessary delays and administrative costs of having to subject a proposed land development ordinance to a vote.

87. Rosenberg, supra note 8 , at 432 .

88. $I d$. 
importantly, the expertise of city planners and commissions became subject to a layman's interpretation of incomprehensible language on the ballot. The process of community planning and land use was merely lengthened and became subject to the whimsical nature of the general electorate. ${ }^{89}$ This is exactly the type of arbitrary behavior that Euclid, Eubank, and Roberge sought to prevent by reviewing the criteria necessary to have zoning ordinances in and of themselves comport with due process principles.

\section{Conclusion}

The Supreme Court recognized the importance of a comprehensive planning scheme when it decided Euclid, Eubank, and Roberge. In requiring that an ordinance bear some substantial relation to the public health, safety, morals, or general welfare, the Court reaffirmed the need to comprise long-range plans for land development. At the same time, the Court properly placed those types of decisions in the hands of those in the best position to make them-land planning experts. By passing the power to enact zoning legislation to the general electorate, the Eastlake Court has granted municipalities, and more importantly neighboring property owners, the ability to decide the fate of zoning ordinances. Subjecting a zoning ordinance to such a mandatory referendum might well render the ultimate decision in violation of the Due Process Clause of the Fourteenth Amendment. Moreover, with legislation already geared towards enacting zoning in accordance with a constitutional and comprehensive plan, the use of a referendum that would potentially hinder the enactment of the comprehensive plan without an informed electorate is an unnecessary step causing impediment to the process that already has adequate constitutional safeguards.

89. Id. at 433 . 
HeinOnline -- 29 Urb. Law. 2921997 